\title{
Comparative Assessment of Fertility and Hatchability Traits of Three Phenotypes of Local Chickens in Adamawa State
}

\author{
A.G. Bobbo ${ }^{1}$; M.S. Yahaya ${ }^{2}$ and S.S. Baba ${ }^{3}$ \\ ${ }^{1 \& 3}$ Department of Animal Science and Range Management, Modibbo Adama University of Technology, Yola \\ ${ }^{2}$ Department of Veterinary Virology, University of Maiduguri, Borno
}

\begin{abstract}
The research was carried out to compare the fertility and hatchability traits of naked neck, frizzle and smooth feathered phenotypes of village chickens. The study was carried out at Modibbo Adama University, poultry farm, Yola and it lasted for a period of eight months. Three phenotypes of Sixteen (16) hens and Two (2) cockerels each (48 breeder hens and 6 cocks) were selected and assigned randomly for the study. A total of three hundreds and twenty four fertile eggs were generated for incubation. All the hatchability parameters were significantly different except, hatchability on fertile egg and dead in shell. Hatching egg weight had significant $(P<0.01)$ effect on all the phenotypes. Fertility, hatchability on set eggs, dead embryo, normal and abnormal chicks and average chick weight had significant $(P<0.05)$ effect on all three the phenotypes. There were some correlations among different hatchability traits depending on the phenotype. The correlations were more profound among naked neck. Frizzle and Naked neck and its crosses were superior in most of the hatchability parameters studied. Smooth and its crosses were superior in terms of fertility, percent normal chicks, and average chick weight. It could therefore be concluded that crossing between Smooth and Frizzle feathered chicken produced better fertility and hatchability traits required. I, recommend Smooth Frizzle chickens to be considered and integrated for hatching and rearing programmes.
\end{abstract}

Key words: Phenotypes, hen, cockerels, Fertility, hatchability, dead embryo, normal, abnormal, chicks.

\section{Introduction}

Free-ranging / Scavenging / Local / Indigenous / Runners / Backyard / Native / Bush /Rural / Family / Traditional / Village chickens (Gallus gallus domesticus), are the commonest type of chickens raised in rural, peri- urban and urban household in Nigeria. They are non descriptive and heterogeneous type of birds that differ in size, shape, colour and production according to their genetic constitution. The Local chicken population constitutes $80 \%$ of the total world chicken population. In Africa, there are over 800 million chickens and of these, more than $80 \%$ are Local chickens (Gueye, 1998). In Nigeria, it constitutes about $92 \%$ of 134 million poultry birds (Manchang et al., 2004).Of the $92 \%$, Sonaiya and Olori (1989), reported that $75 \%$ are the smooth multicolored type, $12 \%$ had frizzle feathered, $6 \%$ had naked neck and $4 \%$ are the dwarf chickens. They are economically, nutritionally and culturally important in many countries (Ekue et al., 2002) and contribute substantially to annual meat and egg production (up to $90 \%$ ) for family consumption and for sale (Nwapku et al., 1999; Fayeye et al., 2005). Local chicken are well adapted to hash environmental conditions such as hot or cold weather, rain and periodic feed shortage. Chicken particularly with white colour have been used for many years for therapeutic purposes by traditional healer (Oh, 1987).Similarly they also provide, manure and keep the surrounding environment clean through scavenging on insects, weeds and waste that lie on the ground. Furthermore they are also used as gift during traditional ceremonies. Breeding under the free ranging system of management is random, cock and hens mate in uncontrolled manner (Williams, 1990).It is usually the most aggressive, strong and dominant cock, which sires most offspring in the neighborhood (Williams, 1990).

The most striking feature in relation to village poultry production is low genetic potential of the birds and these include low fertility and hatchability traits, poor egg laying; slow growth rate and late attainment of sexual maturity as well as small body size (Mjojo,1983). Egg size/weight is usually below 40g, while total egg production is usually less than 120 eggs per annum. Scavenging hen may lay 30-60 eggs/hen/year (Safalaoh et al., 1996). While industrialized battery hens lay up to 300 eggs annually.

There are many factors which influence hatchability of eggs and these include storage time, fertility, temperature, relative humidity, ventilation, position of the egg, turning of the egg and candling. Similarly feed variation also affects hatchability (Mussaddeq et al., 2002). Other factors that affect hatchability of a breeding hen include genetic constitution of the embryo, disease, egg size, age and shell quality (King'ori, 2011).Egg weight, fertility, hatchability and late dead in germs varied greatly between feed regimes (Lariviere et al., 2009).Similarly the fertility of an egg is affected by factors directly related to the laying hen such her ability to mate successfully, store sperm, ovulate and finally produce a suitable environment for the formation and development of embryo (Brillard,2003).Fertility also depends on the ability of cock to mate successfully, quantity and quality of semen deposited (Wilson et al., 1979; Brillard., 2003). Wonmeneh et al. (2011) showed 
that breed had a significant effect on the hatchability parameters and also on weight of the day-old chicks. Islam et al. (2002) concluded that breed have little effect on the hatchability of fertile eggs and fertility and hatchability on total eggs is significantly higher in White leg horns compared to White Rock, Rhode Island Red, and Barred Plymouth rock and also the White Leghorn had more positive correlation on hatchability parameters than the other breeds under Bangladesh condition.

So far there are very limited research findings and dearth of information on reproductive performance of different phenotypes of village chickens in Nigeria. This study is strictly designed to compare and assess the egg quality characteristics of three phenotypes of village chickens in Adamawa state.

\section{Study Area}

\section{Materials And Methods}

The study was carried out in the Teaching and Research Farm of the Federal University of Technology, Yola. It is situated at Latitude 9 and 11 North and Longitude 11 and 14 East. The climate is tropical with distinct dry and wet season. The rainfall starts in April and ends in October while Dry season starts in November to March. The state has an annual rainfall of about $700 \mathrm{~mm}-1600 \mathrm{~mm}$ and relative humidity ranges from $5 \%-42 \%$ with the average temperature of $39^{\circ}$ (Adebayo and Tukur, 1999).

\section{Experimental Chickens}

Different phenotypes of experimental chickens were obtained from villages without the history of crossbreeding programmes involving exotic chickens and these represented the foundation stock. The chickens were placed on broad spectrum antibiotics, dewormed using Piperazine salt and treated for ectoparasites. From each phenotype 16 pullet layers and 2 cockerels were randomly selected for the study. The birds were placed on concrete floor full of saw dust at 16 hens per pen. The birds were exposed to natural day light feeding of about 12 hours per day. All the pullets were placed on grower diet and fed at the rate of $80-90 \mathrm{~g} / \mathrm{bird} / \mathrm{day}$. The grower feed contained $15 \%$ crude protein and 2550Kcal Metabolizable energy (ME) per Kg of feed. Grower feed were gradually replaced with layer mash at point of lay (24 weeks). The layer mash contained $16.5 \%$ crude proteins and $2650 \mathrm{kcal} / \mathrm{kg} \mathrm{ME}$ of feed. The chickens were provided with wooden laying boxes for laying. Egg collected twice a day at 10.00 am and $3.00 \mathrm{pm}$ (Appendix 4 and 5).

\section{Statistical analysis \\ Completely Randomized Design (CRD) design was used and all the data generated were analyzed using SPSS 13.0}

\section{Determination of Hatchability Parameters}

A total of three hundred and twenty four hatchable eggs were selected. The selection was done based on the uniform size, good shape, clean shell, no cracks and the weight of the all hatchable eggs before setting was recorded in gram using digital electrical balance. The eggs were disinfected by rubbing with a wet cloth dipped in a powerful disinfectant $\left(\right.$ Morigad $\left.^{\mathrm{R}}\right)$ before storage for seven days. The hatching eggs were then fumigated using potassium permanganate before setting. The incubator (kerosene) was test run for 24 hours to observe if there are any defects. Temperature of $39.4^{\circ} \mathrm{C}\left(103^{\circ} \mathrm{F}\right)$ and $75 \% \mathrm{RH}$ was maintained through out the incubation. Eggs were turned at 2 or 3 hours intervals, at least 5 times daily and candled at Day 7 days and 18 to remove the infertile ones and dead embryo (dead in germs) respectively. Turning was stopped immediately after the last candling. Optimum humidity was ensured three days before hatching.

At the end of day 21 of incubation, the incubator was opened. The number of hatched chicks including the normal, weak, abnormal chicks, dead chicks after hatch, un-hatched eggs and pips were carefully counted and recorded. Chicks which were under sized, poorly feathered, parrot beaked, blind, lame, open navel etc was considered as abnormal. Hatched out chicks was weighed and recorded using digital electric balance. Estimation of fertility, hatchability on fertile eggs, hatchability on set eggs, embryonic mortality, dead in shell, normal and abnormal chicks hatched and the weight of each day old chicks were recorded in gram. The percentage fertility and hatchability were estimated using the relationship below:

Fertility $(\%)=$ No of fertile eggs/ Total no of eggs produced $\times 100 \%$

Hatchability on fertile eggs $(\%)=$ No of eggs hatched out/Total no of fertile eggs $\times 100 \%$

Hatchability on set eggs $(\%)=$ No of eggs hatched out/Total no of eggs set $\times 100 \%$

\section{Results \\ Effect of hen of different phenotypes on hatchability traits:}

The hatchability traits of nine different phenotypes of local chickens are presented in Table 1. All the hatchability traits were significant except hatchability on fertile egg and dead in shell. Hatching egg weight had significant $(\mathrm{P}<0.01)$ effect with 36.30, 40.06, 44.50, 44.48, 40.69, 40.85, 36.91, 38.34 and 40.29g for frizzle $\mathrm{x}$ 
frizzle, frizzle $\mathrm{x}$ naked neck, frizzle $\mathrm{x}$ smooth, naked neck x naked neck, naked neck x frizzle, naked neck x smooth, smooth x smooth, smooth x naked neck, smooth x frizzle respectively. Naked neck produced heaviest egg (44.48) and frizzle produced the lightest (36.00). Fertility had significant $(\mathrm{P}<0.05)$ effect on all the phenotypes with $12.49,50.00,58.20,55.35,43.75,20.8,32.55,66.68$, and $64.81 \%$ for frizzle $\mathrm{x}$ frizzle, frizzle $\mathrm{x}$ naked neck, frizzle x smooth, naked neck x naked neck, naked neck x frizzle, naked neck x smooth, smooth $\mathrm{x}$ smooth, smooth $x$ naked neck, smooth $x$ frizzle respectively. Smooth naked neck (66.68) was the most fertile chicken, followed by smooth frizzle (64.81).and by frizzle (ff) least (12.49). Hatchability on set eggs had a significant $(\mathrm{P}<0.05)$ effect with 8.33, 0.00, 14.86, 12.51, 39.58, 16.66, 9.48, 20.84 and $23.29 \%$ for frizzle $\mathrm{x}$ frizzle, frizzle x naked neck, frizzle x smooth, naked neck x naked neck, naked neck x frizzle, naked neck x smooth, smooth $\mathrm{x}$ smooth, smooth $\mathrm{x}$ naked neck, smooth $\mathrm{x}$ frizzle respectively. Naked neck frizzle produced highest no of day old chicks on hatchability on set than any phenotype. There was no significant difference between the hatchability on fertile eggs on all the phenotypes studied, but apparently naked neck frizzle again produced highest no of day old chicks than any phenotype. Dead embryo had a significant $(\mathrm{P}<0.05)$ effect on the phenotypes with $12.50,25.00,62.98,27.50,12.50,0.00,37.33,16.68$, and $37.44 \%$ for frizzle $x$ frizzle, frizzle $x$ naked neck, frizzle x smooth, naked neck x naked neck, naked neck x frizzle, naked neck x smooth, smooth $\mathrm{x}$ smooth, smooth $\mathrm{x}$ naked neck, smooth $\mathrm{x}$ frizzle respectively. Normal chick had a significant $(\mathrm{P}<0.05)$ effect with25.00, 0.00, 12.30, 19.16, 56.25,37.50,31.08, 37.50 and 83.34\% for frizzle $\mathrm{x}$ frizzle, frizzle $\mathrm{x}$ naked neck, frizzle $\mathrm{x}$ smooth, naked neck x naked neck, naked neck x frizzle, naked neck x smooth, smooth $\mathrm{x}$ smooth, smooth $x$ naked neck, smooth $x$ frizzle respectively. Smooth frizzle produced highest $(\mathrm{P}<0.05)$ percentage of normal day old chicks. Abnormal chicks had a significant $(\mathrm{P}<0.05)$ effect with $0.00,0.00,28.78,28.34,6.25$, $18.93,0.00$ and $4.16 \%$ for frizzle $\mathrm{x}$ frizzle, frizzle $\mathrm{x}$ naked neck, frizzle x smooth, naked neck x naked neck, naked neck $\mathrm{x}$ frizzle, naked neck $\mathrm{x}$ smooth, smooth $\mathrm{x}$ smooth, smooth $\mathrm{x}$ naked neck, smooth $\mathrm{x}$ frizzle respectively. Average chick weight had a significant $(\mathrm{P}<0.05)$ effect with 7.00, 0.00, 15.98, 16.04, 17.46, 12.60, $13.61,11.03,25.63 \mathrm{~g}$, for frizzle $\mathrm{x}$ frizzle, frizzle $\mathrm{x}$ naked neck, frizzle x smooth, naked neck $\mathrm{x}$ naked neck, naked neck $\mathrm{x}$ frizzle, naked neck $\mathrm{x}$ smooth, smooth $\mathrm{x}$ smooth, smooth $\mathrm{x}$ naked neck, smooth $\mathrm{x}$ frizzle respectively. Smooth frizzle chickens produced heavier $(\mathrm{P}<0.05)$ than the other phenotypes (Table 1).

In this study (Table 2), significant positive correlation was found between fertility and hatchability on set eggs $(p<0.01)$, fertility and hatchability on fertile eggs $(P<0.05)$, fertility and dead in shell $(p<0.05)$, fertility and normal chick $(p<0.05)$, fertility and average chick weight $(p<0.01)$, hatchability on set eggs and hatchability on fertile eggs $(p<0.01)$, hatchability on fertile eggs and chick weight $(p<0.01)$, hatchability on set eggs and normal chick $(p<0.01)$, hatchability onset eggs and average chick weight $(p<0.01)$, hatchability of fertile egg and normal chick $(p<0.05)$, normal chick and average chick weight $(p<0.01)$

In this study ( Table 3), significant positive correlation was found between fertility and dead in shell $(p<0.05)$, hatchability on set eggs and hatchability on fertile eggs $(p<0.01)$, hatchability on set eggs and normal chicks $(p<0.01)$, hatchability on set eggs and average chick weight $(p<0.01)$, hatchability of fertile eggs and normal chick $(p<0.01)$, hatchability on fertile eggs and average chick weight $(p<0.01)$, normal chick and average chick weight $(\mathrm{p}<0.05)$. Some significant negative correlation between hatchability on set eggs and dead embryo $(\mathrm{p}<0.05)$, hatchability on fertile eggs and dead embryo $(\mathrm{p}<0.05)$.

In this study (Table 4), significant positive correlation was found between fertility and dead embryo $(p<0.05)$, fertility and dead in shell $(p<0.01)$, hatchability on set eggs and hatchability on fertile egg $(p<0.01)$, hatchability on set eggs and normal chick $(p<0.01)$, hatchability on set eggs and average chick weight $(p<0.01)$, hatchability on fertile eggs and normal chick $(p<0.01)$, hatchability on fertile eggs and average chick weight $(\mathrm{p}<0.01)$, normal chick and average chick weight $(\mathrm{p}<0.01)$.

Table1: Hatchability traits of nine phenotypes of local Chickens.

\begin{tabular}{|c|c|c|c|c|c|c|c|c|c|c|}
\hline \multirow[b]{2}{*}{ Parameters } & \multicolumn{9}{|c|}{ Treatment } & \multirow[b]{2}{*}{ SEM } \\
\hline & 1 & 2 & 3 & 4 & 5 & 6 & 7 & 8 & 9 & \\
\hline Egg weight (g) & $36.30^{\mathrm{d}}$ & $40.06^{\mathrm{bc}}$ & $44.50^{\mathrm{a}}$ & $44.48^{\mathrm{a}}$ & $40.69^{\mathrm{b}}$ & $40.85^{\mathrm{b}}$ & $36.91^{\mathrm{cd}}$ & $38.34^{\mathrm{bcd}}$ & $40.29^{\mathrm{b}}$ & $1.06^{* * *}$ \\
\hline Fertility (\%) & $12.49^{\mathrm{c}}$ & $50.00^{\mathrm{ab}}$ & $58.20^{\mathrm{a}}$ & $55.35^{\mathrm{ab}}$ & $43.75^{\mathrm{abc}}$ & $20.83^{\text {bc }}$ & $32.55^{\mathrm{abc}}$ & $66.68^{\mathrm{a}}$ & $64.81^{\mathrm{a}}$ & $11.37 *$ \\
\hline $\begin{array}{l}\text { Hatchability on set eggs } \\
{[\%]}\end{array}$ & $8.33^{\mathrm{bc}}$ & $0.00^{\mathrm{c}}$ & $14.86^{\mathrm{bc}}$ & $12.51^{\mathrm{bc}}$ & $39.58^{\mathrm{a}}$ & $16.66^{\mathrm{bc}}$ & $9.48^{\mathrm{bc}}$ & $20.84^{\mathrm{abc}}$ & $23.29^{\mathrm{ab}}$ & $6.98^{*}$ \\
\hline $\begin{array}{l}\text { Hatchability on fertile } \\
\text { eggs }[\%]\end{array}$ & $25.00^{\mathrm{ab}}$ & $0.00^{\mathrm{b}}$ & $21.23^{\mathrm{ab}}$ & $19.16^{\mathrm{ab}}$ & $56.25^{\mathrm{a}}$ & $37.50^{\mathrm{ab}}$ & $22.74^{\mathrm{ab}}$ & $33.34^{\mathrm{ab}}$ & $37.03^{\mathrm{ab}}$ & $12.58 \mathrm{NS}$ \\
\hline Dead embryo [\%] & $12.50^{\mathrm{b}}$ & $25.00^{\mathrm{b}}$ & $62.98^{\mathrm{a}}$ & $27.50^{\mathrm{ab}}$ & $12.50^{\mathrm{b}}$ & $0.00^{\mathrm{b}}$ & $37.33^{\mathrm{ab}}$ & $16.68^{\mathrm{b}}$ & $37.44^{\mathrm{ab}}$ & $11.57 *$ \\
\hline Dead shell [\%] & $0.00^{\mathrm{b}}$ & $25.00^{\mathrm{ab}}$ & $15.81^{\mathrm{ab}}$ & $40.84^{\mathrm{a}}$ & $6.25^{\mathrm{ab}}$ & $12.50^{\mathrm{ab}}$ & $26.71^{\mathrm{ab}}$ & $33.33^{\mathrm{ab}}$ & $25.55^{\mathrm{ab}}$ & $10.92 \mathrm{NS}$ \\
\hline Normal chicks [\%] & $25.00^{\mathrm{bc}}$ & $0.00^{\mathrm{c}}$ & $21.23^{\mathrm{bc}}$ & $19.16^{\mathrm{bc}}$ & $56.25^{\mathrm{ab}}$ & $37.50^{\mathrm{bc}}$ & $31.08^{\mathrm{bc}}$ & $37.50^{\mathrm{bc}}$ & $83.34^{\mathrm{a}}$ & $14.14 *$ \\
\hline Abnormal chicks [\%] & 0.00 & 0.00 & 0.00 & 0.00 & 0.00 & 0.00 & 0.00 & 0.00 & 0.00 & $7.40^{*}$ \\
\hline Average chick weigh $[\mathrm{g}]$ & $7.00^{\mathrm{bc}}$ & $0.00^{\mathrm{c}}$ & $15.98^{\mathrm{ab}}$ & $16.04^{\mathrm{ab}}$ & $17.46^{\mathrm{ab}}$ & $12.60^{\mathrm{abc}}$ & $13.61^{\mathrm{abc}}$ & $11.03^{\mathrm{abc}}$ & $25.63^{\mathrm{a}}$ & $4.93^{*}$ \\
\hline
\end{tabular}


$1=$ Frizzle $x$ Frizzle, $2=$ frizzle naked neck, $3=$ frizzle smooth, $4=$ naked neck x naked neck, $5=$ naked neck frizzle, $6=$ naked neck $\mathrm{x}$ smooth, $7=$ smooth $\times$ smooth, $8=$ smooth $\times$ naked neck, $9=$ smooth $\times$ frizzle.

Means on the row with different superscripts are significantly different. $* \mathrm{P}<0.05, * * \mathrm{P}<0.01 * * * \mathrm{p}<0.001$

Table 2: The correlation of different hatchability traits among hens of naked neck

\begin{tabular}{llllllllll}
\hline Parameters & 1 & 2 & 3 & 4 & 5 & 6 & 7 & 8 & 9 \\
\hline 1 & 1.00 & & & & & & & & \\
2 & 0.33 & 1.00 & & & & & & & \\
3 & -0.11 & $0.59^{* *}$ & 1.00 & & & & & & \\
4 & -0.16 & $0.42^{*}$ & $0.82^{* *}$ & 1.00 & & & & & \\
5 & 0.20 & 0.09 & -0.09 & -0.33 & 1.00 & & & & \\
6 & 0.21 & $0.46^{*}$ & -0.21 & -0.22 & -0.21 & 1.00 & & & \\
7 & -0.15 & $0.42^{*}$ & $0.82^{* *}$ & $1.00^{* *}$ & -0.33 & -0.20 & 1.00 & & \\
8 & 0.17 & 0.38 & 0.03 & -0.00 & -0.14 & 0.00 & -0.00 & & \\
9 & 0.00 & $0.54 * *$ & $0.70^{* *}$ & $0.85^{* *}$ & -0.36 & 0.11 & $0.85^{* *}$ & $0.62^{* *}$ & 1.00 \\
\hline
\end{tabular}

KEY: Where 1=Egg weight [g], 2= Fertility [\%], $3=$ Hatchability on set eggs [\%], $4=$ Hatchability on fertile eggs $[\%], 5=$ Dead embryo $[\%], 6=$ Dead shell $[\%], 7=$ Normal chicks, $8=$ Abnormal chicks [\%], $9=$ chick weight $[\mathrm{g}]$, । $* \mathrm{P}<0.05, * * \mathrm{p}<0.01$

Table 3: The correlation of different hatchability traits among hens of smooth feathered

\begin{tabular}{|c|c|c|c|c|c|c|c|c|c|}
\hline Parameters & 1 & 2 & 3 & 4 & 5 & 6 & 7 & 8 & 9 \\
\hline 1 & 1.00 & & & & & & & & \\
\hline 2 & 0.29 & 1.00 & & & & & & & \\
\hline 3 & 0.10 & 0.31 & 1.00 & & & & & & \\
\hline 4 & -0.08 & 0.09 & $0.90^{* *}$ & 1.00 & & & & & \\
\hline 5 & -0.20 & -0.07 & $-0.49 *$ & $-0.49 *$ & 1.00 & & & & \\
\hline 6 & 0.15 & $0.51^{*}$ & -0.21 & -0.33 & -0.25 & 1.00 & & & \\
\hline 7 & 0.13 & 0.18 & $0.82 * *$ & $0.83^{* *}$ & -0.29 & -0.29 & 1.00 & & \\
\hline 8 & -0.18 & 0.01 & 0.04 & 0.04 & -0.07 & 0.20 & -0.14 & 1.00 & \\
\hline 9 & 0.09 & 0.18 & $0.76^{* *}$ & $0.77^{* *}$ & -0.31 & -0.18 & $0.87^{* *}$ & 0.33 & 1.00 \\
\hline
\end{tabular}

KEY: Where 1= Egg weight [g], 2 = Fertility [\%], $3=$ Hatchability on set eggs [\%], $4=$ Hatchability on fertile eggs $[\%], 5=$ Dead embryo $[\%], 6=$ Dead shell $[\%], 7=$ Normal chicks $[\%], 8=$ Abnormal chicks $[\%], 9=$ Average chick weight $[\mathrm{g}]$.

$* \mathrm{p}<0.05, * * \mathrm{p}<0.01$.

Table 4: The correlation of different hatchability traits among hens of frizzle

\begin{tabular}{|c|c|c|c|c|c|c|c|c|c|}
\hline Parameters & 1 & 2 & 3 & 4 & 5 & 6 & 7 & 8 & 9 \\
\hline 1 & 1.00 & & & & & & & & \\
\hline 2 & 0.24 & 1.00 & & & & & & & \\
\hline 3 & 0.12 & 0.27 & 1.00 & & & & & & \\
\hline 4 & -0.05 & 0.13 & $0.89 * *$ & 1.00 & & & & & \\
\hline 5 & 0.27 & $0.50^{*}$ & -0.10 & -0.17 & 1.00 & & & & \\
\hline 6 & 0.21 & $0.52 * *$ & -0.15 & -0.18 & -0.15 & 1.00 & & & \\
\hline 7 & -0.15 & -0.13 & $0.89 * *$ & $0.94 * *$ & -0.17 & -0.18 & 1.00 & & \\
\hline 8 & 0.39 & 0.31 & $0.48^{*}$ & 0.25 & 0.20 & -0.04 & 0.29 & & \\
\hline 9 & 0.20 & 0.26 & $0.86^{* *}$ & $0.83 * *$ & 0.01 & -0.15 & $0.83^{* *}$ & $0.78 * *$ & 1.00 \\
\hline
\end{tabular}

KEY: Where 1 = Egg weight $[\mathrm{g}], 2$ = Fertility [\%], 3 = Hatchability on set eggs [\%], $4=$ Hatchability on fertile eggs [\%], 5 $=$ Dead embryo $[\%], 6=$ Dead shell $[\%], 7=$ Normal chicks $[\%] 8=$ Abnormal chicks $[\%], 9=$ Average chick weight $[\mathrm{g}]$.

$* \mathrm{p}<0.05, * * \mathrm{p}<0.01$ 


\section{Discussion \\ Effect of hen of different phenotypes on hatchability traits:}

The mean hatchable egg weight in the present study was lower than values reported for Lohmann silver and Potchefstroom Koekoek breeds of chicken (Wondmeneh et al., 2011). Similarly the result is also lower than values reported for Barred Plymouth Rock, White Leghorn, Rhode Island Red (Islam et al., 2002) on Bangladesh local chickens. But the mean egg weight for most phenotypes compares favorably with figures reported for Horro and Fayoumi, breeds of chickens reported elsewhere (Wondmeneh et al., 2011). Furthermore the findings is higher than the values reported (Joseph and Oduntan, 1999; Fayeye et al., 2005) from unclassified Nigerian local chickens and Fulani- ecotype chicken respectively. The result is also slightly higher than values reported by (Yakubu et al., 2008) for naked neck chickens chicken but, slightly lower than values reported for Smooth feathered chickens. The reason adduced for these differences could be the type 1of feed used and age of the chickens. Age, feed, protein level and temperature are some of the factors that affect egg size in chickens (Banerjee, 1992). Fertility (66.68\%) obtained in this study is slightly lower than (Fayeye et al., 2005; Wondmeneh et al., 2011, Islam et al., 2002). The lower fertility could be probably due to heat stress encountered during incubation, as greater part of the study was carried out during the dry season (February July). Similarly the fertility of an egg is affected by the factors directly related to the laying hen such as her ability to mate successfully, store sperm, ovulation an egg cell, and finally produces a suitable environment for the formation and development of the embryo (Brillard, 2003). Furthermore fertility also depends on the ability of the cock to mate successfully, quantity and quality of semen deposited (Wilson et al., 1979; Brillard, 2003), male and female ratio, age, preferential mating, lightening. Highest fertility, normal chicks and heaviest weight of the day old chicks recorded in this study by normal smooth feathered is in agreement with Sonaiya and Olori (1989) who stated that, $75 \%$ of the total chickens population in Nigeria are smooth multicolored and this suggest the supremacy of the phenotype over the others. The values obtained on hatchability on set eggs in this study is far lower than values obtained elsewhere (Islam et al., 2002) and it is also lower than values reported (Wondmeneh et al., 2011) on Ethiopian local chickens. The lower hatchability in this study is due excessive thickness of the eggs. Poor hatchability generally in this study is probably due to fluctuation in environmental temperature, relative humidity and ventilation stress, which is a common phenomenon in this part of the world. Similar observations were made by Bibek and colleagues (2003) elsewhere. Other factors that have considerable influence on hatchability include nutrition of the breeding hens, genetic constitution of the embryo, disease, egg size, age and shell quality (King' ori, 2011). Egg weight, fertility, hatchability and late embryonic mortality varied greatly with feed regimes (Lariviere et al., 2009). Highest percentage of dead embryo obtained in the study is far higher than the results reported by Islam et al. (2002), but tend to agree with Singh et al. (1983) who reported $36.9 \%$ and $45.2 \%$ white leghorn and white Plymouth Rock respectively. This is probably due to efficacy of the incubator used. Highest production of percent normal chicks in this study is slightly lower than Wondmeneh et al. (2011), who reported $91.72 \%, 95.98 \%, 89.48 \%$ and $94.18 \%$ for Horo, Fayoumi, Lohmann, Silver and Potchefstroom Koekoek breeds of chickens respectively.

Live healthy chickens obtained in the study were lower than Wondmeneh et al. (2011). The authors obtained higher percentage of healthy normal chicks in Ethiopian breeds. Increased production of sound chicks is an indication of successful hatchability. Average chicks weight recorded in the study was slightly lower than the values reported by different researchers elsewhere (Islam et al., 2002; Wondmeneh et al., 2011) for Bangladesh and Ethiopian breed of local chickens respectively. Normal feathered produced heaviest and healthiest chicks and this support the earlier work by Kalita, (1994) and Abiola et al. (2008) who showed that the best values were achieved with medium size eggs and comparatively large size eggs always not resulted heavier chicks and phenotypes may have a significant role (Islam et al., 2002). Thus the result also signifies that chick weight was not just a function of egg weight, but it was also altered by genetic background. Egg weight is a phenotypic characteristic.

The present result indicated significant positive correlation for all phenotypes between fertility and dead in shell; hatchability on set eggs and hatchability of fertile eggs; hatchability on set eggs and normal chick; hatchability on set eggs and chick weight; hatchability on fertile eggs and chick weight and dead in shell and normal chick, the afore mentioned findings compares favorably with (Islam et al., 2002), except fertility and dead in shell and dead in shell and normal chicks which contradicts (Islam et al., 2002), low relative humidity during incubation is associated with these types of hatchability traits. The non significant correlation found between the egg weight and all the hatchability parameters in all the three phenotypes studied, disagreed with Islam et al. (2002) who reported significant positive correlation between egg weight and some hatchability parameters on Bangladesh chickens. Naked neck showed significant positive correlation than others for fertility and hatchability on set eggs, fertility and hatchability on fertile eggs, fertility and normal chicks, and fertility and chick weight. The result of the study is comparable with Islam et al. (2002) reported on white leg horn and Rode Island Red (Table 2). The negative value recorded between hatchability on set eggs and dead embryo and hatchability on fertile eggs and dead embryo recorded by Smooth feathered chickens in the study is similar to 
the results obtained by Islam (2002) on Barred Plymouth Rock, White Leghorn, Rhode Island Red and White Rock chickens elsewhere (Table 3). On the contrast significant positive correlation obtained in the present study between fertility and dead embryo by Frizzle feathered chickens is compared favorably with Islam et al., (2002) on white Leghorn hens (Table 4).

\section{Conclusions:}

There was no significant correlation of hatchable egg weight on all the three phenotypes and in all the hatchability parameters studied. On the contrast there was strong significant positive correlation between dead in shell and fertility, hatchability on set eggs and hatchability of fertile eggs, hatchability on set eggs and normal chicks, hatchability on set eggs and chick weight, hatchability on fertile eggs and normal chick, hatchability on fertile egg and chick weight, normal chick and chick weight in the three phenotypes studied. Furthermore there was also significant positive correlation between hatchability on set eggs and fertility, hatchability on fertile eggs and hatchability on set eggs, normal chick and fertility, chick weight and fertility in naked neck chickens. Strong significant positive correlation is also established between dead embryo and fertility in frizzle chickens.

\section{Recommendations}

Since there is no single phenotype that combines the ability of good fertility, hatchability, survivability and high egg production, I, strongly recommend Smooth Frizzle chickens to be considered and integrated for hatching programmes.

\section{References}

[1]. Abiola, S.S., Meshioye, O.O., Oyerinde B.O. and Bamgbose M.A. (2008). Effect of Egg size on hatchability of broiler chiks. Arch. Zootech., 57: $83-86$.

[2]. Adebayo A. A. and Tukur A. L. (1999), Adamawa State in maps department of geography Federal University of Technology Yola in cooperation with paraclete publishers Yola, Nigeria pp $23-26$

[3]. Banerjee, G. C (1992). Poultry. Mohan Primlani for Oxford and IBH publ. Co. Pvt, Ltd. New Delhi, India. Pp 191

[4]. Bibeck,(2003). Production of day- old chicks and evaluation of compound broider feeds manufactured in Bangladesh. Unpublished research work $1-43$.

[5]. Brillard, J.P., (2003).Practical aspects of fertility in Poultry. World Poultry Science Journal 59: 441-446.

[6]. Ekue, F.N., K.D. Pone, M.J. Mafeni, A.N. Nfi and J. Njoya, 2002. Survey of the Traditional Poultry Production System in the Bamenda Area,Cameroon. In: Characteristics and Parameters of Family Poultry Production in Africa, FAO and IAEA (Eds.). International Atomic Energy Agency, Vienna, Austria, ISBN-13: 9789057820946, pp: 15-25.

[7]. Fayeye, T. R., Adeshiyan, A. B and Olugbami, A. A. (2005) Egg traits, hatchability and early growth performance of the Fulaniecotype Livestock Research for Rural Development. 17(8)

[8]. Gueye, E. F, (1998). Village egg and fowl meat production in Africa Worlds Poultry Sciences Journal, 54: 73-86.

[9]. Islam, M. S. Howlider M. A. R., Kabir F and Alam J. (2002). Comparative Assessment of Fertility and Hatchability of Barred Plymouth Rock, White Leghorn, Rode Island Red and White Rock hen. International Journal of Poultry Science 1 (4): 85-90.

[10]. Joseph, J. K. and Oduntan, R. O. (1999). Egg quality traits as influenced by sources of eggs. Proceedings of $26^{\text {th }}$ Annual NSAP conference, 21-25 March, 1999, Ilorin

[11]. Kalita, N. (1994). Effect of weight, storage period and position of egg on hatchability Indian Journal of poultry Science, 29(30): 8183 .

[12]. King, ori, A. M.,(2011).Review of the factors influence egg fertility and hatchability in Poultry. International Journal of Poultry Science 10: 483-492.

[13]. Lariviere, J. M., Michaux, F. Farnir, j.Detilleux, V. Verleyen and Leroy, P (2009).Reproductive performance of the ardennaise chicken breed under traditional and modern breeding management systems. International Journal of Poultry Science 8: 446-451.

[14]. Manchang,T. K., Abdu, P.A and Saidu, L. (2004)Epidemiology and Clinicopathologic manifestations of Newcastle disease in Nigeria Local chickens. Revue Elev, Med, Vet, Pays, Trop, 57 (1-2): 35-39.

[15]. Merat P. (1990) Pleiotropic and associated effects of major genes In: Crawford R. D., (ed), Poultry breeding and genetics, Elsevier, Amsterdam. Pp. 442- 448

[16]. Mjojo, D. P.K (1983) Comp of production and reproduction performance of Black Australorp and local chickens, Degree project, Bunda college of Agriculture, University of Malawi.

[17]. Mussadideq, Y., Daud, S. and Akhtar, (2002). Astudy on the laying performance of cross (FAY+ RIR) chickens under different plans of feeding. International Journal Poultry Science 1: 188-192.

[18]. Nwakpu, P. E., Odo. B. I., Omeje, S. E.,Akpa, M and Edogo, C.C (1999). Hatching performance of three strains of layer-type chickens and their lines.Proceedings of the $26^{\text {th }}$ Annual Conference of the Nigerian Society for Animal Production.21-25 ${ }^{\text {th }}$ March, Ilirin, Pp118-120. Oh, B. T. (1987). Malaysia: Economic importance In: Newcastle Disease food pellet vaccine(Ed) Copland J.W.). ACIAR monograph .no 5.Canberra, 83-85.

[19]. Orunmuyi, M., Oni,O.O., Adeyinka, I. A and Aseribo, O.E (2007). Genetic parameter estimates for Plasma alkaline phosphate activity and reproductive traits In two strains of rhode island chickens. Asian Journal Animal Science.1: 76-81.

[20]. Safaloah, A. C. L., Kadegi, H.J.L. and Phoyar R.K.D. (1996).Growth performance and carcass characteristics of male black ausralop, dwarf Malawi local chicken and their crosses from 8-20 weeks of age. Uniswa Res, .J. Agric Sci, and Tech 1 (1):61-67.

[21]. Singh, D. K., Singh, C. S. P., Singh, L. B. K. K., and Singh, U. C (1983). Studies on some fertility and hatchability characters in White Leghorn and White Rock chickens. Avian Res., 1978, 676:57-59. In: Poult Abstr. (1986). 12: 106.

[22]. Sonaiya, E. B., and Olori, V. E. (1989) Village chickens production in south western Nigeria In: Proceedings on the International workshop on rural poultry development Africa (Sonaiya E. B; Ed), Pp 243-247.

[23]. Wilson, H.R., Piesco, N.P, Miller, E.R. and Nebseth,W.R (1979).Prediction of the fertility potential of broiler breeder males. World poultry Science Journal 35: 95-118. 
[24]. Williams, G. E. S.(1990).Small holder rural production in Ghana. In: Host, P (1990).Research and development perspective from CTA-Seminar proceeding: Small holder Local poultry production. Riest U (Ed). Thessaloniki Greece 9-13.October 1:89-97.

[25]. Wondmeneh, E. Dawud, I and Adey, M (2011).Comparative Evaluation of Fertility and Hatchability of Horro, Fayoumi, Lohmann Silver and Potchefstroom Koekoek Breeds of Chickens. Asian Journal of Poultry Science, 5 124-129.

[26]. Yakubu A. Oga O. M and Barde R. E (2008). Productivity and Egg Quality Characteristics of Free Range Naked Neck and Normal feathered Nigerian indigenous Chickens. International Journal of Poultry Science, 7 (6): 579-588.

[27]. Zelleke, G.Moudgal and Amare,A(2005). Fertility and hatchability in Rhode Island Red and White Leghorn breeds as functionally modified by crossing them in alternate sex combination (Gallus domesticus).British Poultry Science. 46: 119-123. 